\title{
PENGARUH PENGGUNAAN FILTER BUTTERWORTH PADA PENENTUAN WAKTU TIBA GELOMBANG P
}

\author{
Sesar Prabu Dwi Sriyanto ${ }^{1}$, Yusuf Hadi Perdana ${ }^{2}$ \\ ${ }^{1}$ Stasiun Geofisika Winangun, Manado, Sulawesi Utara, Indonesia \\ ${ }^{2}$ Pusat Penelitian dan Pengembangan BMKG, Kemayoran, Jakarta, Indonesia \\ e-mail: sesar.sriyanto@bmkg.go.id, yusuf.perdana@bmkg.go.id
}

\begin{abstract}
Abstrak
Penentuan waktu tiba gelombang $\mathrm{P}$ cukup sulit apabila Signal to Noise Ratio (SNR) rendah. Pemfilteran sinyal dengan rentang frekuensi yang sesuai dapat meningkatkan SNR, namun apabila rentang frekuensi tidak sesuai, fase gelombang $P$ akan terdistorsi dan penentuan waktu tiba gelombang $P$ tidak tepat. Pada penelitian ini dilakukan analisis pengaruh penggunaan 3 jenis filter Butterworth orde 5 pada waktu tiba gelombang $P$. Jenis filter Butterworth kausal yang digunakan yaitu, filter lowpass $2 \mathrm{~Hz}$, bandpass $2-6 \mathrm{~Hz}$, dan highpass $6 \mathrm{~Hz}$. Hasilnya, secara umum penggunaan filter memberikan efek keterlambatan fase dan pelemahan impuls awal gelombang $P$ yang menyebabkan kesalahan penentuan waktu tiba gelombang $\mathrm{P}$. Jenis filter yang paling bagus digunakan adalah filter bandpass karena kesalahan penentuan waktu tiba gelombang $P$ rata-rata 0,271 detik. Hal ini disebabkan karena gelombang $P$ memiliki frekuensi dominan rata-rata $3,83 \mathrm{~Hz}$. Sementara itu, pemfilteran dengan lowpass dan highpass rata-rata kesalahan masing-masing sebesar 2,183 detik dan 0,347 detik.
\end{abstract}

Kata kunci: waktu tiba gelombang $P$, filter Butterworth, rasio sinyal terhadap bising

\begin{abstract}
$P$ wave arrival time picking is quite difficult in low signal to noise ratio (SNR) condition. This SNR condition could be increased by using digital filter. To optimize the digital filter for increasing SNR, filter frequency range must be suitable with dominant frequency of first impulse of $\mathrm{P}$ wave. In this study, we analyze the effect of the $5^{\text {th }}$ order Butterworth filter on $P$ wave onset. The types of Butterworth causal filter that we use are lowpass $2 \mathrm{~Hz}$, bandpass 2-6 Hz, and highpass $6 \mathrm{~Hz}$. Results indicated that filter causes the delay effect and $P$ wave first impuls amplitude reduction. $P$ wave picking using bandpass filter has the minimum error with an average of 0.271 seconds, because of the dominant frequency of $P$ wave is $3.83 \mathrm{~Hz}$. Meanwhile, the picking that use lowpass and highpass have the error average 2.183 and 0.347 seconds, respectively.
\end{abstract}

Keywords : $\mathrm{P}$ wave arrival time, Butterworth filter, signal to noise ratio

\section{PENDAHULUAN}

Penentuan waktu tiba gelombang $P$ sangat penting dalam kegiatan monitoring gempabumi. Pekerjaan ini merupakan rutinitas yang dilakukan observer di stasiun seismik. Claerbout (1964) menyebutkan bahwa masalah utama pada penentuan waktu tiba gelombang $P$ adalah menentukan fase awal gelombang seismik dalam bising, sehingga sangat bergantung pada kondisi gelombang yang terekam di masing-masing stasiun. Apabila gelombang yang terekam memiliki Signal to Noise
Ratio (SNR) rendah maka cukup sulit untuk mengidentifikasi fase awal gelombang $P$ karena impuls awal gelombang tersamarkan oleh bising. Bising tidak hanya melemahkan gelombang seismik namun juga mempengaruhi kesalahan dalam estimasi parameter gempabumi akibat kesalahan penentuan waktu tiba gelombang $P$. Parameter-parameter gempabumi seperti origin time (OT), posisi episenter gempabumi, dan magnitudo gempabumi sangat penting dalam analisis lanjutan untuk 
memperoleh model mekanisme sumber gempabumi.

Proses pemfilteran gelombang seismik digunakan untuk meningkatkan nilai SNR, dengan harapan impuls awal gelombang $P$ dapat teridentifikasi dengan baik (Claerbout, 1964). Proses pemfilteran ternyata tidak sepenuhnya dapat meningkatkan SNR atau memperjelas impuls awal gelombang $P$ akibat ketergantungannya pada rentang frekuensi yang diloloskan. Apabila frekuensi pojok filter yang digunakan tidak sesuai, maka akan terjadi distorsi pada sinyal seismik yang menyebabkan fase awal gelombang $\mathrm{P}$ sulit diidentifikasi (Douglas, 1997).

Menurut Havskov dan Ottemöller (2010), proses pemfilteran pada gelombang seismik akan menyebabkan keterlambatan fase dan reduksi impuls awal. Hal ini disebabkan oleh adanya perpindahan energi ke sinyal bagian belakang dari proses pemfilteran yang berlangsung dari ujung sinyal kemudian dilanjutkan secara bertahap hingga keseluruhan sinyal. Douglas (1997) juga menyebutkan bahwa hasil pemfilteran lebih cenderung mengalami reduksi amplitudo lebih dari yang dibutuhkan daripada mendapatkan SNR yang optimum. Pada Gambar 1 ditunjukkan contoh hasil pemfilteran gelombang seismik yang menyebabkan keterlambatan fase dan reduksi impuls awal.

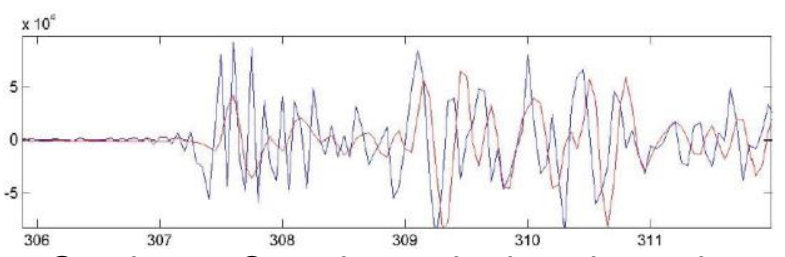

Gambar 1. Contoh overlay impuls awal

sinyal yang belum difilter (warna biru) dan setelah difilter Butterworth bandpass orde 5 (warna merah) (Perdana, 2016).

Tujuan dalam penelitian ini adalah mengetahui pengaruh dari proses pemfilteran sinyal pada fase awal gelombang $P$. Perubahan yang signifikan pada fase awal gelombang $P$ baik dalam nilai amplitudo maupun kandungan frekuensi akan berdampak pada kesalahan hasil perhitungan parameter kinematik, dinamik, dan parameter sumber (Perdana,
2016). Hasil penelitian ini diharapkan memberikan referensi pada observer gempabumi dalam memilih filter yang digunakan sehingga dapat lebih efektif dalam meningkatkan akurasi penentuan waktu tiba gelombang $P$.

\section{Filter Butterworth}

Filter pada dasarnya dilakukan untuk meningkatkan fitur tertentu dan menekan fitur lain yang tidak diinginkan (Haskov dan Ottemöller, 2010). Filter sinyal digital dibutuhkan untuk mendapatkan sinyal yang diinginkan dengan mereduksi gangguan atau bising yang terkandung dalam sinyal (Laghari dkk, 2014). Filter bekerja dengan cara meloloskan hanya rentang frekuensi yang terkandung pada sinyal yang diinginkan. Terdapat 3 jenis filter berdasarkan rentang frekuensi yang dibatasi, yaitu filter lowpass yang meloloskan frekuensi di bawah frekuensi pojok, filter highpass yang meloloskan frekuensi di atas frekuensi pojok, dan filter bandpass yang meloloskan frekuensi di antara 2 frekuensi pojok yang ditentukan (Haskov dan Ottemöller, 2010).

Filter Butterworth merupakan salah satu metode desain filter klasik yang paling banyak digunakan (Paarmann, 2003). Berdasarkan penelitian Laghari, dkk (2014), filter Butterworth memiliki respon amplitudo passband yang hampir datar (maximally flat) dan tidak memiliki riak sehingga relatif lebih baik daripada filter Chebyshev dan Elliptic yang juga termasuk desain filter yang umum digunakan. Magnitudo dari fungsi transfer desain filter Butterworth lowpass dalam domain frekuensi dapat dirumuskan sesuai persamaan berikut (Paarmann, 2003) :

$\left|H_{B}(j \omega)\right|=\frac{1}{\sqrt{1+\left(\frac{\omega}{\omega_{c}}\right)^{2 N}}}$

Keterangan :

$\omega=$ Frekuensi sudut

$\omega_{\mathrm{c}}=$ Frekuensi pojok

$N=$ Orde filter

$\mathrm{j}=\sqrt{-1}$ 


\section{METODE PENELITIAN}

Data yang digunakan merupakan gelombang gempabumi yang terekam di stasiun seismik SKJI (Sukabumi, Jawa Barat) dalam rentang waktu bulan Januari hingga Juni 2016. Stasiun SKJI merupakan salah satu stasiun seismik dalam jaringan BMKG yang terletak di Pelabuhanratu, Jawa Barat dengan koordinat $7,01^{\circ}$ LS dan $106,56^{\circ}$ BT. Sensor yang digunakan merupakan seismometer broadband velocity dengan sampling frequency $20 \mathrm{~Hz}$. Posisinya yang terletak pada jalur sesar Cimandiri memungkinkan untuk mendeteksi gempabumi-gempabumi berkekuatan mikro yang terjadi di sesar tersebut. Selama rentang waktu Januari hingga Juni 2016, stasiun SKJI merekam sebanyak 68 kejadian gempabumi dengan rentang magnitudo lokal (MI) 2,4 hingga magnitude momen (Mw) 6,1 yang sebaran episenternya ditunjukkan pada Gambar 2.

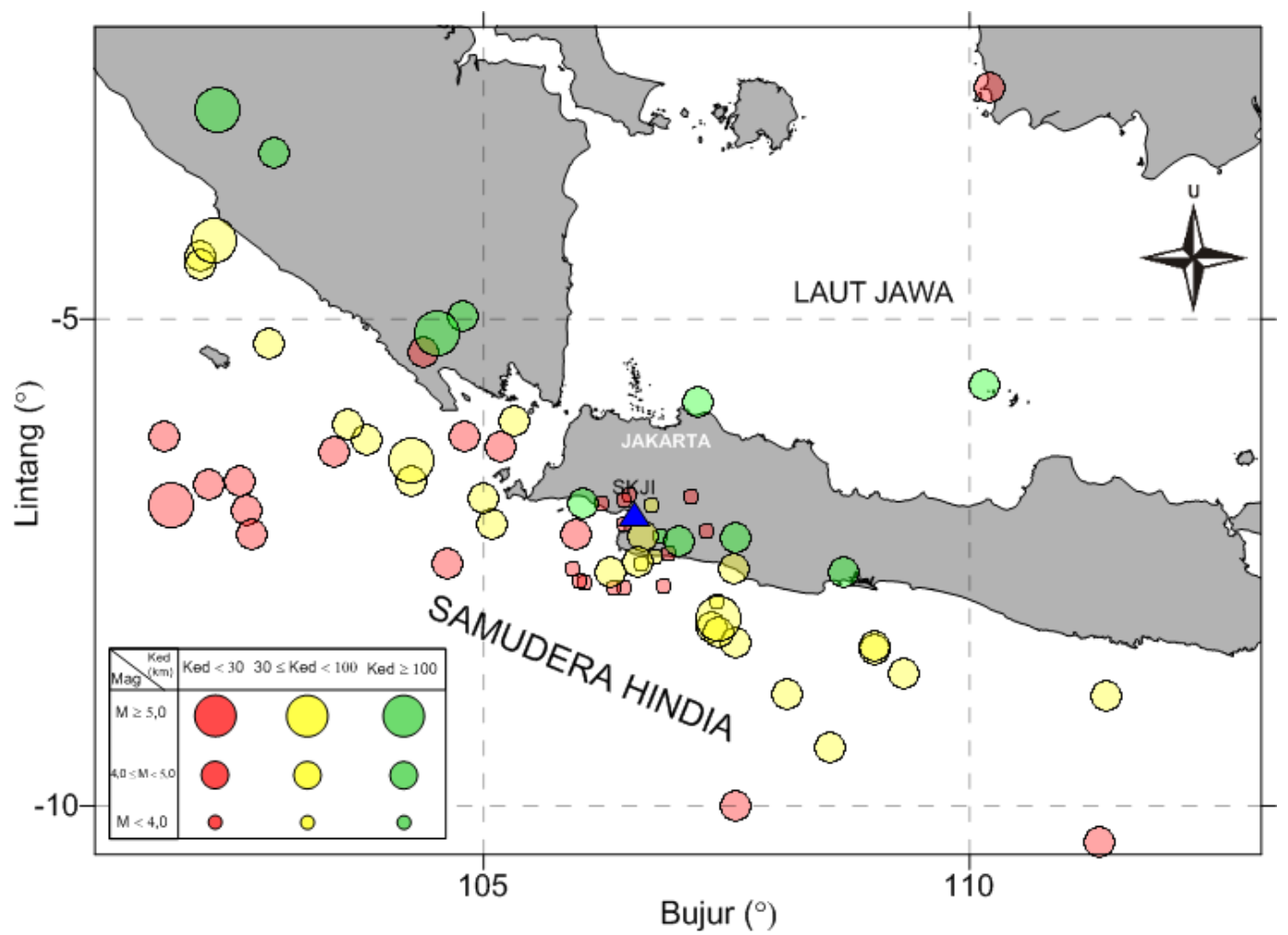

Gambar 2. Peta lokasi stasiun SKJI dan sebaran episenter gempabumi yang dianalisis.

Penelitian ini dilakukan dengan menganalisis karakteristik amplitudo dan frekuensi dominan dari fase awal gelombang $P$ sebelum dilakukan pemfilteran dan setelah pemfilteran. Filter yang digunakan adalah filter Butterworth kausal lowpass 2 $\mathrm{Hz}$, bandpass 2-6 Hz, dan highpass $6 \mathrm{~Hz}$, dengan orde filter 5 . Rentang filter tersebut dipilih dengan mempertimbangkan rentang frekuensi gelombang $P$ gempabumi magnitudo lebih dari 2 yang berkisar antara
0,01-10 Hz (Haskov dan Ottemöller, 2010) dan frekuensi bising yang bervariasi bergantung dari jenis pembangkitnya (Havskov dan Alguacil, 2010). Gambar 3. menunjukkan fungsi transfer filter Butterworth lowpass, bandpass, dan highpass. Tampak bahwa rentang frekuensi yang tidak diloloskan memiliki magnitudo respon bernilai kurang dari $1 \mathrm{~dB}$, yang menunjukkan terjadinya reduksi amplitudo pada kandungan frekuensi tersebut. 
a)

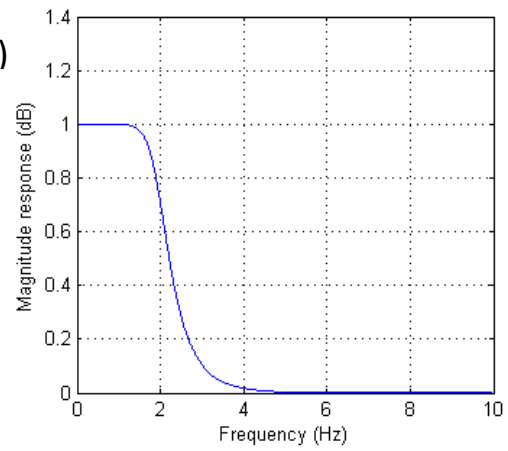

b)

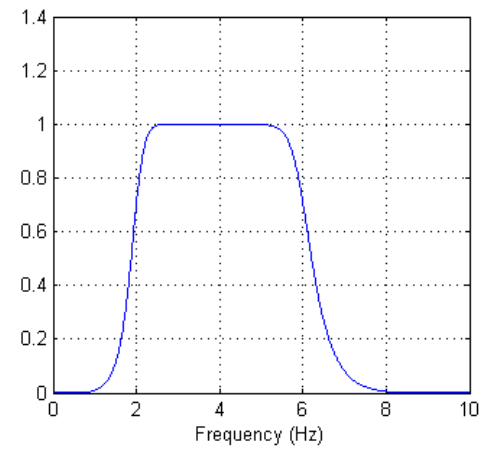

c)

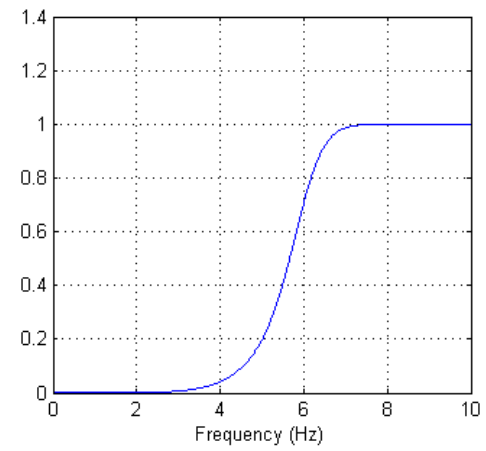

Gambar 3. Fungsi transfer filter Butterworth (a) lowpass $2 \mathrm{~Hz}$, (b) bandpass 2-6 Hz, dan (c) highpass $6 \mathrm{~Hz}$.

Waktu tiba gelombang ditentukan terlebih dahulu secara manual sebelum diterapkan filter. Penentuan waktu tiba gelombang dengan cara manual ini dijadikan sebagai acuan batas antara segmen sinyal dan segmen bising. Segmen bising merupakan deretan gelombang dengan waktu kurang dari waktu tiba gelombang $P$ sedangkan segmen sinyal merupakan deretan gelombang dengan waktu lebih dari atau sama dengan waktu tiba gelombang $P$. Lebar jendela waktu untuk analisis amplitudo dan kandungan frekuensi masingmasing adalah 2 detik dan 5 detik. Lebar jendela waktu 2 detik digunakan untuk melihat tingkat perubahan amplitudo secara tiba-tiba pada gelombang gempabumi, sedangkan lebar jendela waktu 5 detik digunakan untuk melihat frekuensi dominan pada segmen bising dan segmen sinyal.

Perbedaan karakter amplitudo pada segmen sinyal seismik dan bising dihitung secara kuantitatif dengan SNR dalam satuan $\mathrm{dB}$ (desibel), yang dirumuskan sebagai berikut (Afegbua dan Ezomo, 2013):

$S N R=20 \log \frac{A_{S}}{A_{n}}$

dengan $A_{s}$ merupakan nilai akar rata-rata kuadrat (Root Mean Square atau RMS) amplitudo pada segmen sinyal seismik, sedangkan $A_{n}$ merupakan nilai RMS amplitudo pada segmen bising. Nilai SNR menunjukkan rasio amplitudo sinyal seismik terhadap bising seismik. Semakin tinggi nilai SNR maka dapat dianggap sinyal seismik yang terekam dalam seismometer tersebut semakin jelas terlihat.
Kandungan frekuensi pada segmen sinyal seismik dan bising ditinjau dengan melakukan tranformasi Fourier cepat (Fast Fourier Transform atau FFT) dari sinyal masing-masing segmen. Teknik FFT dari sinyal dirumuskan sebagai berikut (Brigham, 1988) :

$S\left(f_{k}\right)=\sum_{i=0}^{N-1} s\left(t_{i}\right) e^{-j 2 \pi f_{k} t_{i}}\left(t_{i+1}-t_{i}\right)$

$k=0,1, \ldots, N-1$

dengan $s\left(t_{i}\right)$ adalah amplitudo sinyal pada waktu ke-i dan $S\left(f_{k}\right)$ merupakan hasil transformasi Fourier dalam domain frekuensi.

\section{HASIL DAN PEMBAHASAN}

Sejumlah 68 sinyal yang dianalisis memiliki SNR yang bervariasi mulai dari 1,55 $\mathrm{dB}$ hingga 48,63 dB. Nilai SNR 1,55 dB merupakan sinyal dari gempabumi berkekuatan Mw 4,6 dengan posisi episenter $\pm 48 \mathrm{~km}$ Selatan Bengkulu. Jarak yang cukup jauh dari stasiun SKJI, yaitu sekitar $572,74 \mathrm{~km}$, menyebabkan sinyal gempabumi tersebut memiliki impuls gelombang $P$ yang lemah. Sementara itu, nilai SNR terbesar berasal dari gempabumi Mw 6,1 yang memiliki jarak episenter 150,82 km. Gempabumi yang terjadi sekitar $123 \mathrm{~km}$ Timur Laut Garut ini merupakan gempabumi berkekuatan terbesar yang terekam di SKJI dalam rentang waktu Januari hingga Juni 2016.

Nilai SNR sangat dipengaruhi oleh magnitudo dan jarak episenter gempabumi secara bersamaan karena getaran gempabumi yang terekam di seismometer 
merupakan konvolusi dari fungsi sumber gempabumi dan medium penjalaran gelombang seismik (Stein dan Wysession, 2003) yang secara umum direpresentasikan oleh magnitudo dan jarak episenter. Pengaruh kedua faktor ini tidak bisa dipisahkan, seperti yang dapat dilihat pada Gambar 4a dan b. Hubungan SNRmagnitudo dan SNR-jarak episenter yang diplot secara terpisah tidak membentuk hubungan yang linier. Di lain pihak, Gambar 4c yang menunjukkan kontur sebaran SNR terhadap magnitudo dan jarak episenter tampak bisa lebih menjelaskan keterkaitan jarak episenter dan magnitudo yang saling mempengaruhi SNR. Berdasarkan Gambar 4c dapat dilihat bahwa secara umum kontur SNR yang tinggi berhubungan dengan kejadian gempabumi magnitudo besar yang memiliki jarak episenter dekat.

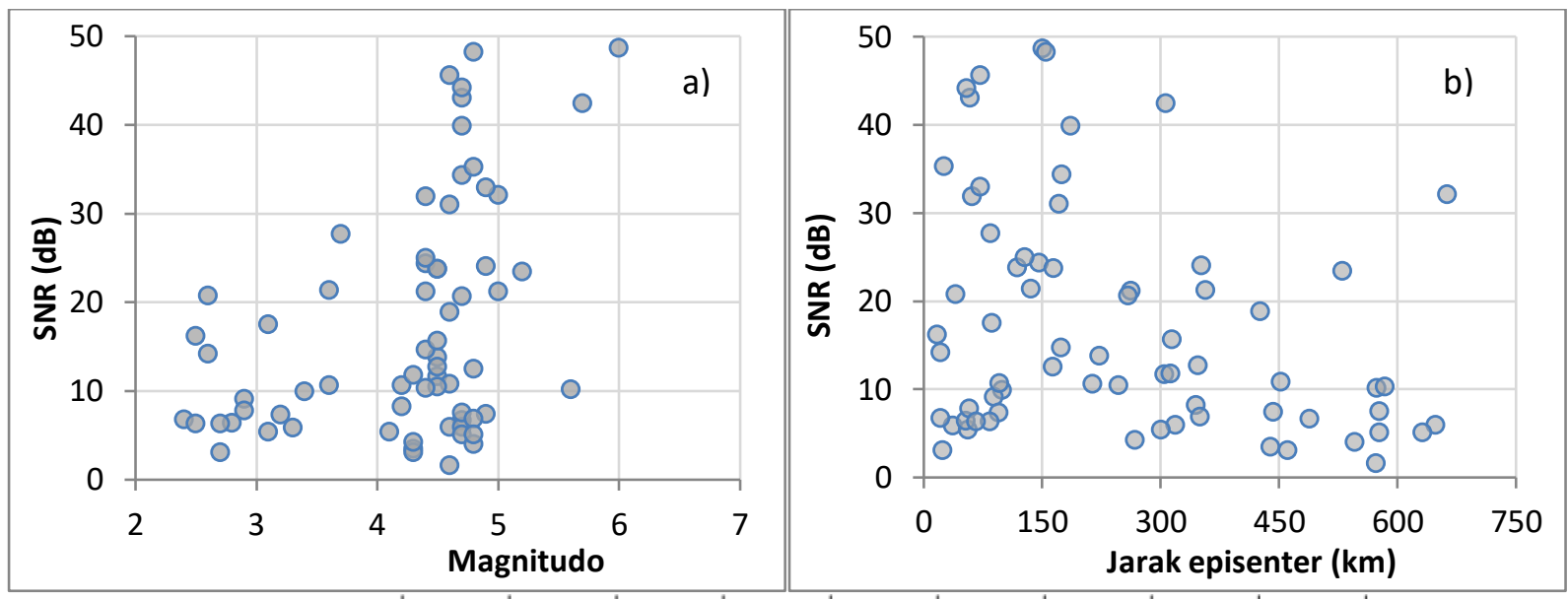

c)

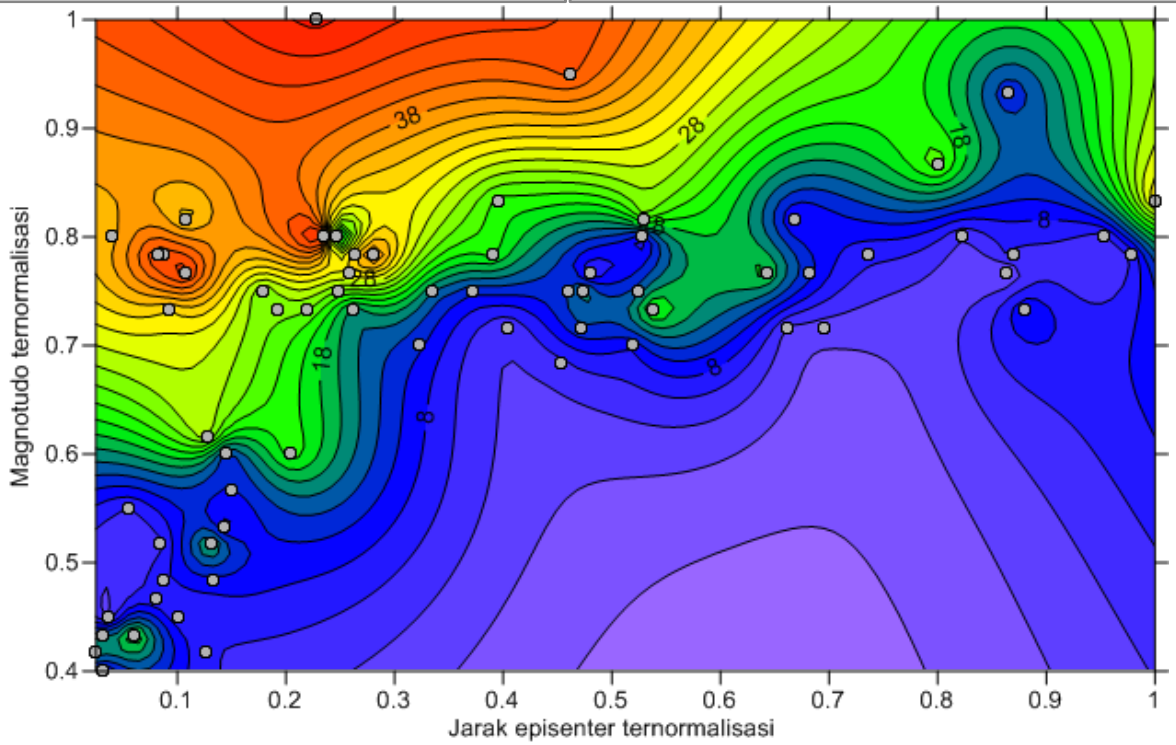

Gambar 4. (a) Plot grafik SNR terhadap magnitudo dan (b) SNR terhadap jarak episenter. (c) kontur hubungan SNR terhadap magnitudo dan jarak episenter ternormalisasi.

Filter Butterworth yang diterapkan pada gelombang gempabumi menyebabkan perubahan karakteristik gelombang. Gambar 5. menunjukkan sinyal hasil pemfilteran dengan lowpass, bandpass, dan highpass yang memperlihatkan bahwa terjadi pelemahan impuls awal gelombang $P$. Impuls awal gelombang $P$ yang bersifat dilatasi dapat dilihat dengan jelas pada sinyal sebelum difilter (Gambar 5a). Pada sinyal hasil pemfilteran lowpass dan bandpass tampak bahwa fase awal bergeser ke kanan, sedangkan pada hasil pemfilteran highpass impuls awal tidak lagi terlihat dengan jelas dan amplitudo sinyal mengalami atenuasi.

Adanya perubahan karakteristik gelombang setelah dilakukan pemfilteran Jurnal Sains dan Teknologi | 172 
menyebabkan keteramatan impuls awal gelombang $P$ oleh observer juga berubah. Penentuan fase awal gelombang $P$ sangat dipengaruhi oleh perubahan amplitudo dan kandungan frekuensi gelombang P. Apabila setelah dilakukan pemfilteran waktu dimana teramati perubahan amplitudo dan kandungan frekuensi bergeser, maka dimungkinkan pula penentuan waktu tiba gelombang $\mathrm{P}$ oleh observer juga bergeser.
Pada dasarnya waktu tiba gelombang $\mathrm{P}$ merupakan waktu dimana gelombang seismik pertama kali tiba di stasiun sehingga lebih sesuai bila diamati pada seismogram asli tanpa pengolahan lanjutan. Oleh karena itu, pergeseran penentuan waktu tiba gelombang $P$ yang terjadi akibat pemfilteran dapat disebut sebagai kesalahan penentuan waktu tiba gelombang $P$.
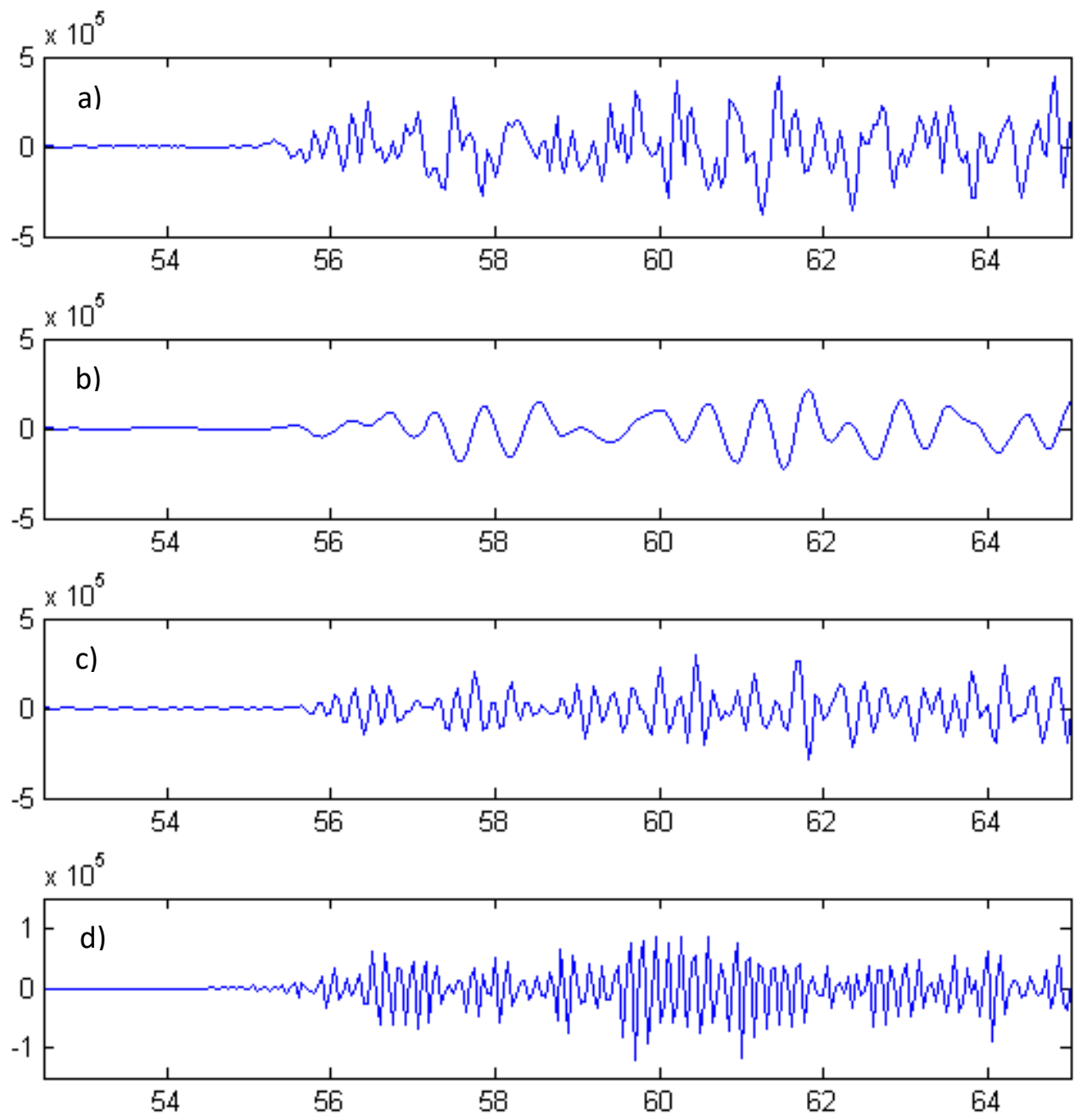

Gambar 5. (a) Contoh sinyal gempabumi yang difilter. (b) Sinyal hasil filter lowpass $2 \mathrm{~Hz}$, (c) bandpass 2-6 Hz, dan (d) highpass $6 \mathrm{~Hz}$.

Hasil pemfilteran dengan filter Butterworth lowpass $2 \mathrm{~Hz}$ menunjukkan bahwa terjadi kesalahan pembacaan fase awal gelombang $\mathrm{P}$ rata-rata 2,183 detik, sedangkan bila menggunakan filter Butterworth bandpass dan highpass masingmasing nilai kesalahan pembacaan rata-rata 0,271 detik dan 0,347 detik. Hubungan antara kesalahan pembacaan waktu tiba fase awal gelombang $P$ dengan SNR ditunjukkan pada Gambar 6, yang menunjukkan bahwa kondisi sinyal dengan SNR rendah memiliki kesalahan waktu pembacaan terbesar setelah dilakukan pemfilteran. 


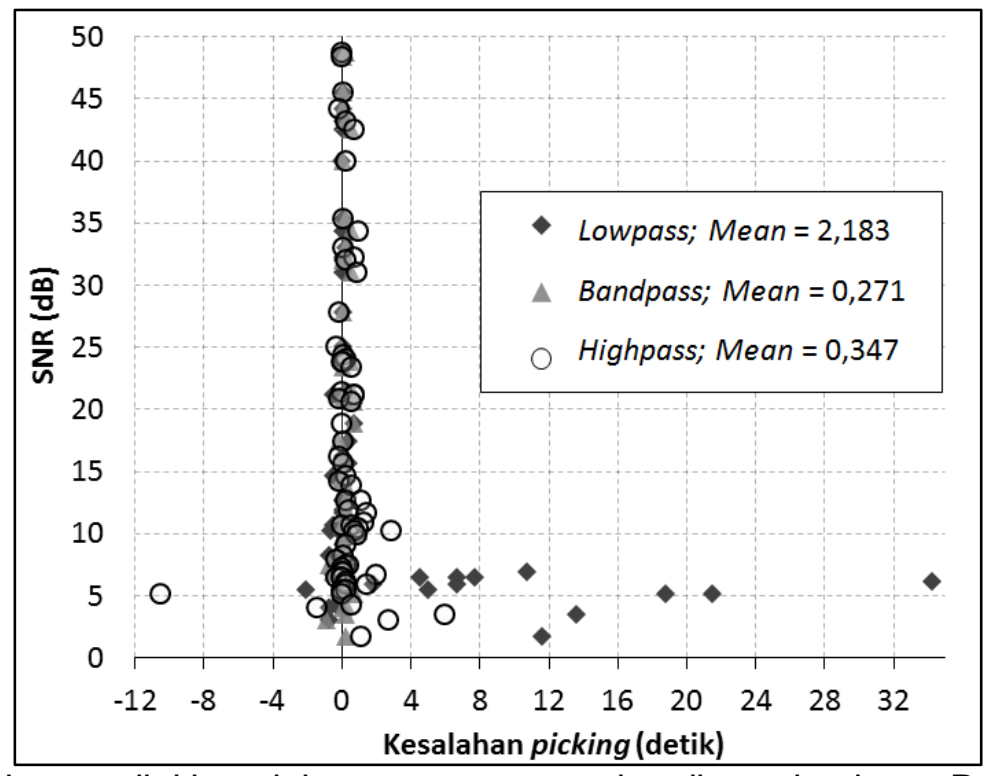

Gambar 6. Sebaran nilai kesalahan penentuan waktu tiba gelombang P terhadap SNR

Nilai kesalahan pembacaan fase awal gelombang $\mathrm{P}$ terbesar terjadi pada kejadian gempabumi Mw 4,7 dengan jarak episenter $648,55 \mathrm{~km}$. Sinyal kejadian gempabumi ini terekam lemah di stasiun SKJI dengan SNR $5,94 \mathrm{~dB}$ dan frekuensi dominan 4,63 Hz. Setelah dilakukan filter lowpass $2 \mathrm{~Hz}$, sinyal tidak menunjukkan peningkatan SNR namun terjadi penurunan SNR menjadi 1,98 dB. Hal ini terjadi karena frekuensi dominan bising seismik bernilai $0,496 \mathrm{~Hz}$ sehingga pemfilteran menggunakan lowpass $2 \mathrm{~Hz}$ lebih memperkuat bising dan menjadi pereduksi sinyal gelombang $P$. Kandungan frekuensi fase awal gelombang $P$ yang dominan pada rentang 2,5-5,5 $\mathrm{Hz}$ terjadi penurunan setelah dilakukan filter lowpass yang menyebabkan kandungan frekuensinya menjadi mirip kandungan frekuensi bising seismik, seperti yang ditampilkan pada Gambar 7. Akibatnya, saat dilakukan penentuan waktu tiba gelombang $P$ terjadi kesalahan pembacaan hingga 34,251 detik setelah waktu tiba gelombang $P$ sebenarnya.
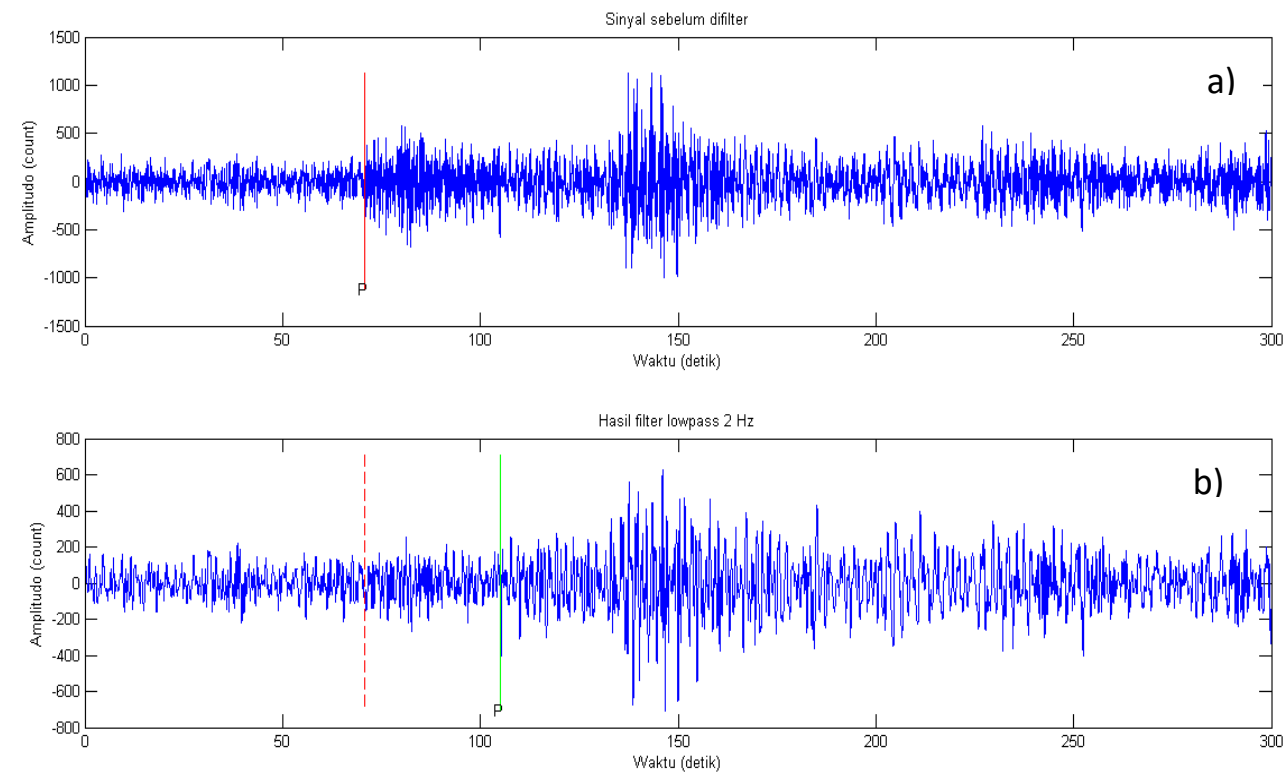

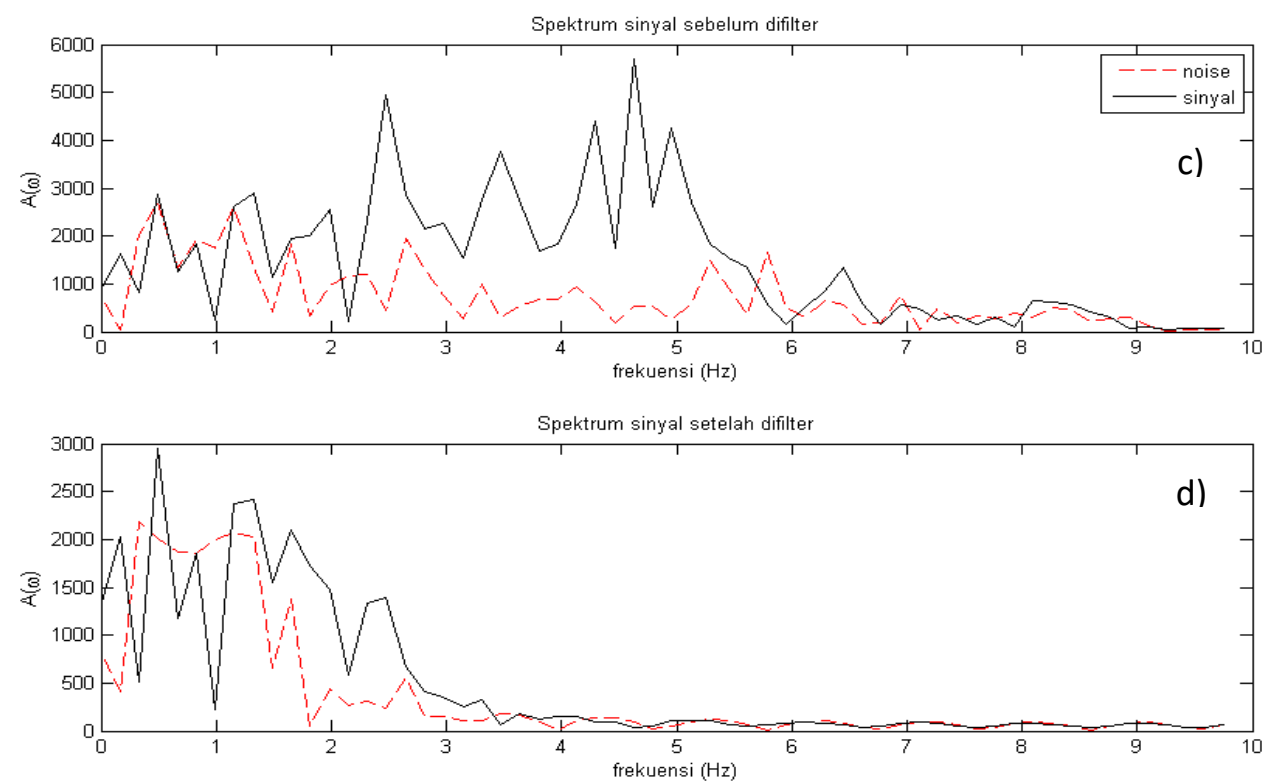

Gambar 7. (a) Gelombang sebelum difilter dengan garis merah adalah hasil pembacaan fase $\mathrm{P}$, dan (b) Sinyal yang telah difilter lowpass dengan garis hijau dan putus-putus merah masingmasing adalah hasil pembacaan fase P setelah dan sebelum difilter. (c) Spektrum pada segmen sinyal dan bising sebelum difilter, dan (d) spektrum pada segmen sinyal dan bising setelah difilter.

Kesalahan pembacaan fase awal gelombang $P$ yang cukup besar juga terjadi pada sinyal gempabumi hasil filter highpass. Sejumlah 13 kesalahan pembacaan bernilai lebih dari \pm 1 detik dengan kesalahan terbesar bernilai 5,98 detik. Sebagian besar dari sinyal tersebut merupakan sinyal gempabumi dengan jarak episenter jauh, yaitu antara 163 hingga $632 \mathrm{~km}$. Jarak yang jauh menyebabkan kandungan frekuensi yang terekam di SKJI didominasi oleh frekuensi rendah sehingga penggunaan filter highpass menyebabkan tereduksinya fase awal gelombang P. Gambar 8. menunjukkan gelombang gempabumi berjarak $573,9 \mathrm{~km}$ dengan frekuensi dominan $2,314 \mathrm{~Hz}$. Amplitudo gelombang $\mathrm{P}$ mengalami reduksi setelah diterapkan filter highpass sehingga terjadi kesalahan pembacaan fase awal gelombang $\mathrm{P}$.

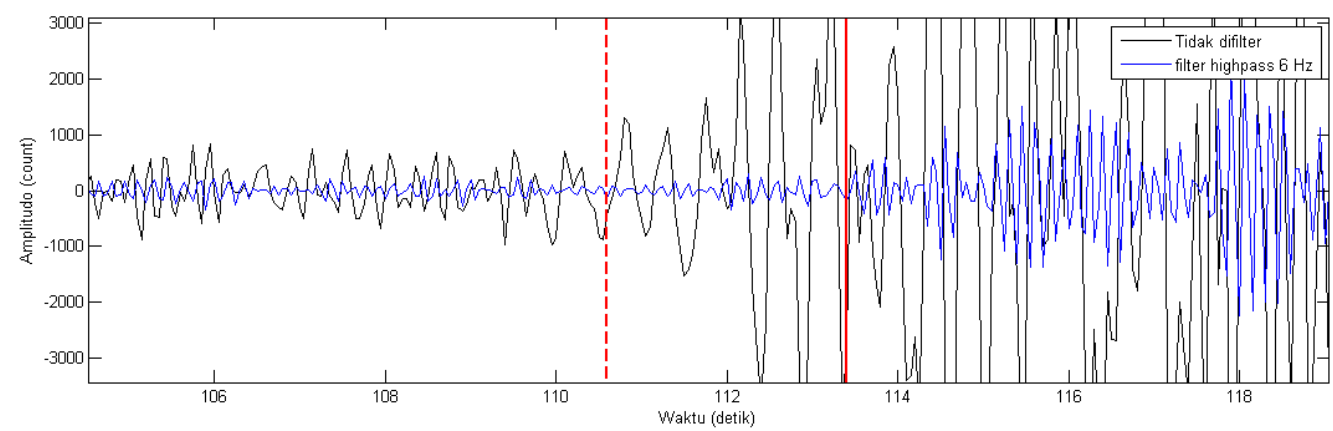

Gambar 8. Gelombang seismik sebelum difilter (warna hitam) dan setelah difilter highpass $6 \mathrm{~Hz}$ (warna biru), dengan garis merah dan putus-putus merah masing-masing adalah hasil pembacaan fase $P$ setelah dan sebelum difilter.

Penggunaan filter bandpass mampu meminimalisir kesalahan pembacaan fase awal gelombang $\mathrm{P}$ karena filter tersebut meloloskan sinyal pada rentang frekuensi 2$6 \mathrm{~Hz}$, sehingga kandungan frekuensi gelombang $\mathrm{P}$ yang bernilai rata-rata $3,83 \mathrm{~Hz}$ dapat terlingkupi. Hal ini juga menyebabkan bising seismik yang memiliki kandungan frekuensi di luar rentang $2-6 \mathrm{~Hz}$ dapat tereduksi. 
Berdasarkan hasil ini, filter highpass merupakan filter yang mampu meningkatkan nilai SNR dengan rata-rata peningkatan sebesar $0,57 \mathrm{~dB}$. Nilai ini berbanding terbalik dengan hasil dari filter bandpass dan lowpass yang menyebabkan penurunan SNR masing-masing bernilai rata-rata 3,54 $\mathrm{dB}$ dan $0,65 \mathrm{~dB}$. Filter highpass dapat meningkatkan SNR karena kandungan frekuensi bising lebih dominan pada frekuensi rendah sehingga apabila dilakukan filter highpass $6 \mathrm{~Hz}$ maka amplitudo spektral segmen sinyal seismik dominan lebih besar daripada amplitudo spektral segmen bising. Gambar 9. merupakan salah satu contoh hasil pemfilteran highpass yang berhasil meningkatkan SNR dari 27,65 dB menjadi $39,12 \mathrm{~dB}$. Meskipun terlihat terjadi reduksi amplitudo gelombang $P$ namun filter highpass yang digunakan mampu meredam bising yang memiliki frekuensi dominan 2,81 $\mathrm{Hz}$.

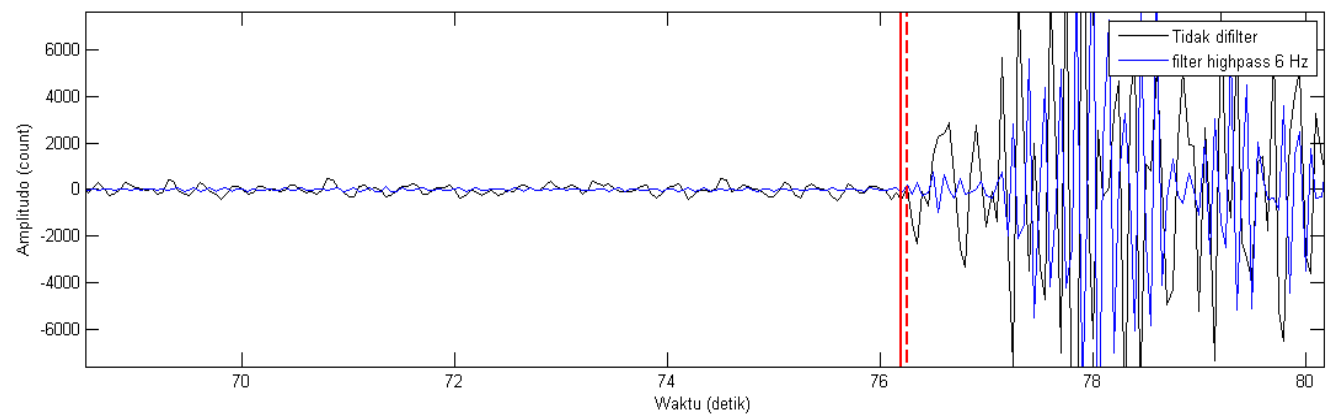

Gambar 8. Contoh hasil pemfilteran highpass $6 \mathrm{~Hz}$ dengan sinyal warna hitam merupakan sinyal sebelum difilter dan sinyal warna biru merupakan sinyal setelah difilter. Garis merah dan putus-putus merah masing-masing adalah hasil pembacaan fase $P$ setelah dan sebelum difilter.

Meskipun dapat meningkatkan SNR secara signifikan namun penggunaan highpass secara umum dapat mereduksi kandungan frekuensi pada impuls awal gelombang $P$ yang rata-rata dominan pada frekuensi $3,83 \mathrm{~Hz}$. Hal ini menyebabkan penggunaan highpass tetap memiliki kesalahan pembacaan fase awal gelombang $P$ yang lebih besar daripada penggunaan filter bandpass.

\section{SIMPULAN}

Hasil penelitian ini menunjukkan bahwa penggunaan filter memberikan efek keterlambatan fase dan pelemahan impuls awal gelombang $P$ sehingga dapat menyebabkan kesalahan penentuan waktu tiba gelombang $P$. Pemfilteran tidak selalu memberikan peningkatan kondisi SNR karena bergantung dari rentang frekuensi filter yang digunakan. Apabila rentang frekuensi filter sesuai dengan frekuensi dominan gelombang $\mathrm{P}$ dan menapis frekuensi dominan bising maka akan didapatkan hasil pemfilteran yang optimum. Secara umum, filter terbaik yang dapat digunakan untuk mempermudah pembacaan fase awal gelombang $\mathrm{P}$ adalah filter yang meloloskan frekuensi dominan gelombang $\mathrm{P}$ yang bernilai $3,83 \mathrm{~Hz}$ dan menapis frekuensi dominan bising yang bernilai $2,95 \mathrm{~Hz}$, yakni filter bandpass $2-6$ $\mathrm{Hz}$.

\section{UCAPAN TERIMAKASIH}

Penulis mengucapkan terimakasih kepada Badan Meteorologi Klimatologi dan Geofisika (BMKG) atas data seismik yang dapat digunakan dalam penelitian ini. Selanjutnya, ucapan terimakasih juga ditujukan kepada seluruh Civitas Akademika STMKG yang telah mendukung kegiatan penelitian ini baik secara moril maupun materiil.

\section{DAFTAR PUSTAKA}

Afegbua, K.U., dan Ezomo, F.O. 2013. A Preliminary Investigation of the Signalto-noise Ratio of Toro and Nsukka Stations in Nigeria. International Journal of Physical Science, Vol. 8, No. 16, 707-716. 
Brigham, E.O. 1988. The Fast Fourier Transform FFT and Its Applications. Prentice-Hall Inc., New Jersey.

Claerbout, J.F. 1964. Detection of P-Waves From Weak Sources at Great Distances. Geophysics, Vol. 29, No. 2, 197-211.

Douglas, A. 1997. Bandpass Filtering to Reduce Noise on Seismograms : Is There a Better Way ?. Bulletin of the Seismological Society of America, Vol. 87, No. 4, 770-777.

Havskov, J., dan Ottemöller, L. 2010. Routine Data Processing in Earthquake Seismology. Springer, New York.

Havskov, J., dan Alguacil, G. 2010. Instrumentation in Earthquake Seismology. Springer, Dordrecht.
Laghari, W.M., Baloch, M.U., Mengal, M.A. and Shah, S.J. 2014. Performance Analysis of Analog Butterworth Low Pass Filter as Compared to Chebyshev Type-I Filter, Chebyshev Type-II Filter and Elliptical Filter. Circuits and Systems, Vol. 5, 209216.http://dx.doi.org/10.4236/cs.2014. 59023

Stein, S., dan Wysession. 2003. Introduction to Seismology, Earthquakes and Earth Structure, Blackwell, Oxford.

Paarmann, L.D. 2003. Design and Analysis of Analog Filters : A Signal Processing Perspective. Kluwer Academic Publishers, New York.

Perdana, Y.H. 2016. Perancangan Filter Butterworth Infinite Impulse Response untuk Gelombang Gempabumi. Skripsi, STMKG, Tangerang Selatan. 